\title{
Letrozole: an emerging array of hope for infertile women
}

\author{
Manish Maladkar $^{1 *}$, Chitra Tekchandani², Akshata Karchodi ${ }^{3}$
}

\author{
${ }^{1}$ Department of Scientific, Medical and Regulatory Affairs, Aristo Pharmaceuticals Private Limited, Mumbai, \\ Maharashtra, India \\ ${ }^{2}$ Department of Scientific, Medical, Aristo Pharmaceuticals Private Limited, Mumbai, Maharashtra, India \\ ${ }^{3}$ Department of Scientific, Aristo Pharmaceuticals Private Limited, Mumbai, Maharashtra, India
}

Received: 26 July 2019

Revised: 19 November 2019

Accepted: 28 November 2019

\section{*Correspondence:}

Dr. Manish Maladkar,

E-mail: scientific@aristopharma.org

Copyright: (C) the author(s), publisher and licensee Medip Academy. This is an open-access article distributed under the terms of the Creative Commons Attribution Non-Commercial License, which permits unrestricted non-commercial use, distribution, and reproduction in any medium, provided the original work is properly cited.

\begin{abstract}
Ovulation induction has been a major breakthrough in the management of female infertility since many decades. Letrozole, an aromatase inhibitor has been used as a potential therapy for ovulation induction. A large number of clinical evidences have been emerging which cite the beneficial role of Letrozole in conditions like anovulatory infertility, polycystic ovary syndrome (PCOS), unexplained infertility and an incipient role in endometriosis- related infertility with regards to higher live-birth rates. Letrozole is a superior alternative to Clomiphene citrate (CC) which has been used conventionally as ovulation inducer. Clomiphene citrate has certain well-defined disadvantages, whereas Letrozole overcomes these limitations to a reasonable extent. The peripheral anti-estrogenic effect of CC leads to prolonged depletion of estrogens receptors, adversely affecting endometrial growth and development as well as quantity and quality of cervical mucus. Persistent blockade of estrogen receptor leads to CC resistance and is associated with reduced ovulation and pregnancy rates. Available evidences suggest Letrozole is superior to CC owing to the lack of persistent anti-estrogenic action due to its short half- life and lack of action on estrogen receptors. This typically leads to monofollicular growth and also higher live birth rates. The current evidences suggest that Letrozole can be placed as first line therapy for the management of infertility due to PCOS and unexplained infertility.
\end{abstract}

Keywords: Anti-estrogenic effects, Anovulation, Aromatase inhibitors, Clomiphene citrate resistance, Infertility, Oral ovulation inducers, Polycystic ovary syndrome, Unexplained infertility

\section{INTRODUCTION}

A basic paradox surrounding human reproduction is that even though reproduction is critical for the survival, the process is highly inefficient in some individuals. ${ }^{1}$

Infertility, one of the major health issues, is defined as the failure to achieve a clinical pregnancy after 12 months or more of regular unprotected sexual intercourse. ${ }^{2}$ In women greater than 35 years of age, an earlier evaluation is necessary after 6 months of regular unprotected sexual intercourse. ${ }^{3}$ Worldwide, the prevalence of infertility is around $8-12 \% .^{4}$ In India, an estimated 13-19 million couples are expected to be infertile at a given point of time. ${ }^{5}$ Infertility can be diagnosed as primary or secondary infertility. Primary infertility refers to a condition when a woman in the age group of 15-49 years is unable to deliver a live birth after being exposed to unprotected sexual intercourse. Secondary infertility is a condition in which a woman after having successful 
previous pregnancy and live-birth is unable to bear a child, either due to the inability to become pregnant or the inability to carry a pregnancy to a live birth. ${ }^{6}$

\section{Female infertility - a rising concern}

Around $25-40 \%$ of females suffer from infertility. ${ }^{7}$ Advancing age significantly increases the risk of infertility as the fecundity of women tends to decline after the age of 35 years. Lifestyle diseases like obesity, diabetes, stress and anxiety have also been compromising the chances of conception. ${ }^{8}$ One of the major contributors of female infertility has been ovulatory disorders, others being tubal pathology (like blocked fallopian tubes), uterine fibroids and cervical pathology (cervicitis). ${ }^{9}$ Ovulatory disorders result from asynchronous functioning of hypothalamus, pituitary and ovarian axis; subsequently leading to anovulation, oligo-ovulation and irregular menstrual cycles. Diseases of female reproductive tract such as PCOS, endometriosis drastically alter the functioning of female reproductive system eventually causing infertility. Pelvic surgery can induce structural changes in female reproductive tract and further affect the fecundity, ovulation and implantation. ${ }^{10}$

The most widely used treatment for ovulatory disorders is ovarian stimulation which includes ovulation induction, superovulation and controlled ovarian hyperstimulation $(\mathrm{COH})$. This approach is used for treatment of anovulation or oligo-ovulation. Ovulation induction can be achieved by administration of exogenous gonadotropins alone or in combination with Clomiphene citrate or aromatase inhibitor (AI).

\section{Review of literature}

This is a review of the evidences published in the literature. The review was conducted via searching the articles in the databases of Pub Med, Cochrane Database of Systematic Reviews, MEDLINE, Science Direct, Embase, Scopus and Google scholar using key words. All the relevant articles on the topic were reviewed. Amongst which, 43 articles were fully accessed and referenced.

\section{Clomiphene citrate therapy for ovulation induction}

Clomiphene citrate was introduced more than 50 years ago and gained popularity based on the fact that it was highly affordable and possessed various advantages over its injectable and expensive competitors like gonadotropin analogues. Clomiphene citrate as an ovulation inducer was first of its kind that was capable of bringing about a revolution in infertility management. ${ }^{11}$

Clomiphene citrate is structurally similar to estrogen which allows it to bind to estrogen receptors and blocks it. The blockade of estrogen receptors on the hypothalamus prevents the accurate interpretation of circulating estrogen levels. The reduced interpretation of estrogen increases the pulsatile release of gonadotropin releasing hormone $(\mathrm{GnRH})$ which in turn stimulates the release of follicle stimulating hormone (FSH) from pituitary thereby setting the ovarian follicular activity in motion as shown in Figure 1. ${ }^{12}$

\section{Clomiphene citrate isomers - more than meets the eye}

\section{Effect on ovulation rate}

In spite of being used as a conventional ovulation inducer, it is difficult to predict the success rate with Clomiphene citrate regarding ovulation and pregnancy. The reason being, Clomiphene citrate acts as a Selective Estrogen Receptor Modulator (SERM) and contains an unequal mixture of two isomers as their citrate salts, Enclomiphene (62\%) and Zuclomiphene (38\%) displaying mixed agonist and antagonistic properties. Enclomiphene is estrogen antagonist while Zuclomiphene has got mixed estrogenic and anti-estrogenic properties depending upon the target tissue. For e.g.; Zuclomiphene exhibits estrogenic effects in pituitary whereas in cervix and endometrium, it is anti-estrogenic. Due to this property of Zuclomiphene at pituitary level, there is a mid-follicular peak in estrogen levels thereby exerting a positive feedback on GnRH. This is turn leads to luteinizing hormone ( $\mathrm{LH})$ surge and reduction in FSH release, arresting the growth and maturation of oocytes. This greatly hampers the ovulation process leading to reduction in ovulation rate by Clomiphene citrate. ${ }^{12}$

Moreover, Clomiphene citrate is cleared slowly from the body and is detectable in blood for more than a month due to long half-life of approximately 2 weeks. ${ }^{9,13}$ As a consequence, it remains bound to the estrogen receptors leading to desensitization of the receptors. Clomiphene citrate fails to act on these desensitized receptors in the subsequent treatment cycles (if the treatment cycle needs to be repeated) leading to variability in ovulation rates as shown in Figure 1.8

\section{Effect on pregnancy rate}

Clomiphene citrate blocks estrogen receptors on cervix and alters the permeability properties of cervical mucus which hinders the smooth passage of sperm through it to reach the oocyte. This can be explained by the reduction in the peripheral availability of estrogen which is required for increasing the hydration of mucus via water transudation along with small electrolytes thereby resulting in cervical mucus secretion which is watery in nature with low viscosity. ${ }^{13}$

Further, blockade of endometrial estrogen receptors by Clomiphene citrate reduces the availability of estrogen which otherwise directly influences the uterine blood flow by activating endothelial cells. This in turn causes release of endogenous nitric oxide, a potent vasodilator that mediates the uterine blood flow. ${ }^{14}$ Uterine blood flow ensures optimum uterine receptivity which is extremely crucial for embryo nidation. As per a study carried out by 
Omran E et al, endometrial perfusion was significantly lower in Clomiphene citrate-stimulated cycles during peri-implantation when compared to natural ones in patients with unexplained infertility. ${ }^{15}$ Other unfavorable clinical implications of Clomiphene citrate have been summarized in Table 1.

\section{Aromatase inhibitors - a potential alternative as ovulation inducer}

Estrogen is one of the primary steroid hormones for normal female physiology and reproduction. Aromatase, an enzyme containing cytochrome P450 hemoprotein, catalyzes the rate limiting step in the conversion of androstenedione and testosterone to estrogen. The ovarian aromatase is produced in abundance in women during reproductive phase since ovaries are the major site for the production of estrogen. Hence, aromatase can be a good target for selective inhibition of estrogen production thereby correcting ovulatory disorders. ${ }^{19}$

\section{Journey of Letrozole as ovulation inducer}

Over the last 30 years, a large number of aromatase inhibitors have been developed with third generation aromatase inhibitors being licensed for use in hormone receptor-positive breast cancer in post-menopausal women. Following the clinical failure of first- and second-generation aromatase inhibitors owing to significant side effects and below par potency in inhibiting aromatase enzyme, the third-generation aromatase inhibitors like Letrozole and Anastrazole became commercially available for management of breast cancer in post-menopausal women. They were highly potent with $97-99 \%$ reduction of estrogen levels as detected by most sensitive immunoassays. ${ }^{20}$

Table 1: Clomiphene citrate: other unfavorable clinical implications.

\begin{tabular}{|ll|}
\hline $\begin{array}{l}\text { Implications } \\
\text { increased risk of pregnancy } \\
\text { complications }\end{array}$ & $\begin{array}{l}\text { Possible reasons } \\
\text { release of FSH which leads to growth and maturation of more than one follicle. }{ }^{16}\end{array}$ \\
\hline $\begin{array}{l}\text { Clomiphene citrate } \\
\text { resistance }\end{array}$ & $\begin{array}{l}\text { Factors like insulin resistance, hyperandrogenemia, and obesity prevents follicular growth } \\
\text { and maturation in response to increased levels of FSH. }{ }^{17}\end{array}$ \\
\hline $\begin{array}{l}\text { Melayed time to } \\
\text { pregnancy }\end{array}$ & $\begin{array}{l}\text { Presence of Clomiphene citrate resistance or Clomiphene failure (poor quality cervical } \\
\text { chances of desensitization of estrogen receptors, thereby hampering the ovulation process. }\end{array}$ \\
\hline
\end{tabular}

Table 2: Letrozole - favorable clinical implications over Clomiphene citrate.

\begin{tabular}{|c|c|}
\hline Clinical implication & Possible reasons \\
\hline Higher ovulation rate & $\begin{array}{l}\text { Letrozole has no effect on estrogen receptors; it blocks the aromatase enzyme for } 5 \text { days } \\
\text { after which the drug is eliminated from the body. Hence normal physiological process is } \\
\text { resumed leading to higher ovulation rate as compared to Clomiphene citrate. }{ }^{23}\end{array}$ \\
\hline Higher pregnancy rate & $\begin{array}{l}\text { Lack of action on estrogen receptors in cervix and endometrium leads to better } \\
\text { conception and implantation resulting in higher pregnancy rates. }{ }^{23}\end{array}$ \\
\hline $\begin{array}{l}\text { Monofollicular growth and } \\
\text { singleton pregnancy }\end{array}$ & $\begin{array}{l}\text { Letrozole does not exert anti-estrogenic action at the level of estrogen receptors. Hence, } \\
\text { no desensitization of estrogen receptors is observed thereby maintaining the normal } \\
\text { physiological ovulation process. }{ }^{24}\end{array}$ \\
\hline Lesser time to pregnancy & $\begin{array}{l}\text { No action on estrogen receptors and with short half-life of } \sim 45 \text { hours leads to rapid } \\
\text { restoration of normal physiological ovulation process leading to lesser time to achieve } \\
\text { pregnancy. }{ }^{18}\end{array}$ \\
\hline
\end{tabular}

In the purview of preventing estrogen feedback on FSH by blocking aromatase enzyme, Letrozole $2.5 \mathrm{mg}$ was tested for ovulation induction in ten women with polycystic ovary syndrome (PCOS). It was reported that two women had clinical pregnancies. In one more study involving patients with Clomiphene citrate resistance with a thin endometrium, use of Letrozole led to normal endometrial thickness along with estrogen triple line pattern clearly seen. These favorable clinical experiences led to addition of Letrozole in the armamentarium of infertility management as a potent oral ovulation inducer. $^{21}$

\section{Letrozole in ovulation induction ${ }^{22}$}

\section{a. Central mechanism}

Letrozole inhibits the aromatization of androgen to estrogen by blocking the aromatase enzyme. This inhibition of aromatization releases the 
hypothalamic/pituitary axis from estrogenic negative feedback. The resultant increase in gonadotropin secretion stimulates the growth of ovarian follicles. Since, Letrozole has a short half-life of ( $~ 45$ hours); it is rapidly eliminated from the body. Hence, the blockade on the aromatization is removed and hypothalamic-pituitary axis is again able to detect the presence of endogenous circulating estrogen and leads to gradual stoppage of FSH. This results in normal follicle growth, selection of dominant follicle and atresia of other growing follicles. The detection of endogenous circulating estrogen by hypothalamic-pituitary axis also leads to timely release of LH from pituitary gland and finally leads to ovulation as shown in Figure 2.

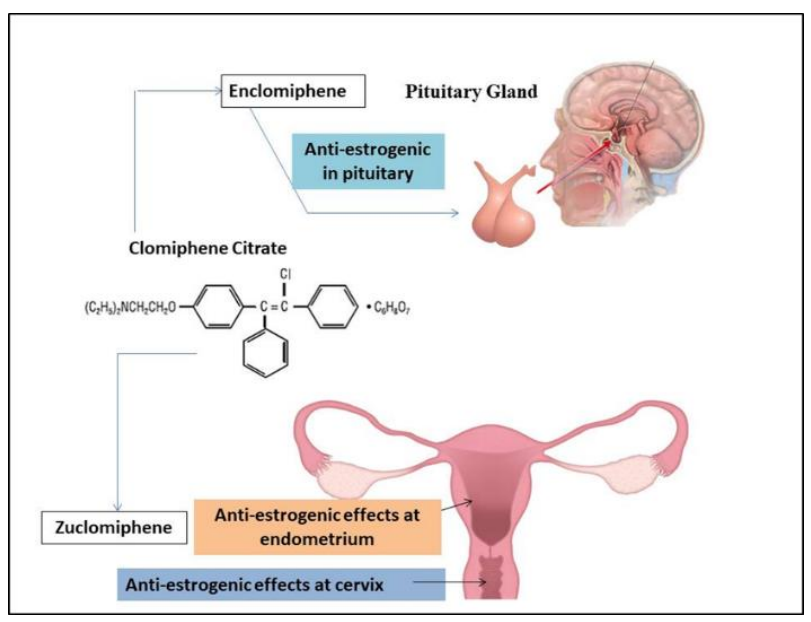

Figure 1: Different actions of Clomiphene citrate isomers in pituitary gland, cervix and endometrium. ${ }^{12}$

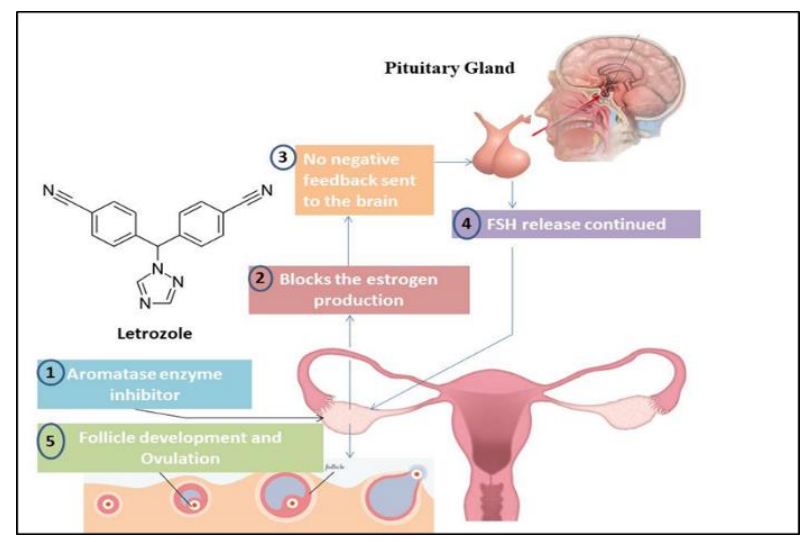

Figure 2: Central mechanism of action (at pituitary level) of Letrozole in ovulation induction. ${ }^{22}$

\section{b. Peripheral mechanism}

The blockade of aromatization in the early follicular phase can lead to increase in intra-ovarian androgen. Intra-ovarian androgen has an important effect on early follicular growth. Androgens increase the number of preantral and small antral follicles as androgens stimulate theca and granulosa cell proliferation and inhibit apoptosis of the follicles. This effect is mediated by androgen receptors which are found to be 4.2-fold higher in granulosa cells from immature follicles than in preovulatory follicles as shown in Figure 3. ${ }^{23,24}$

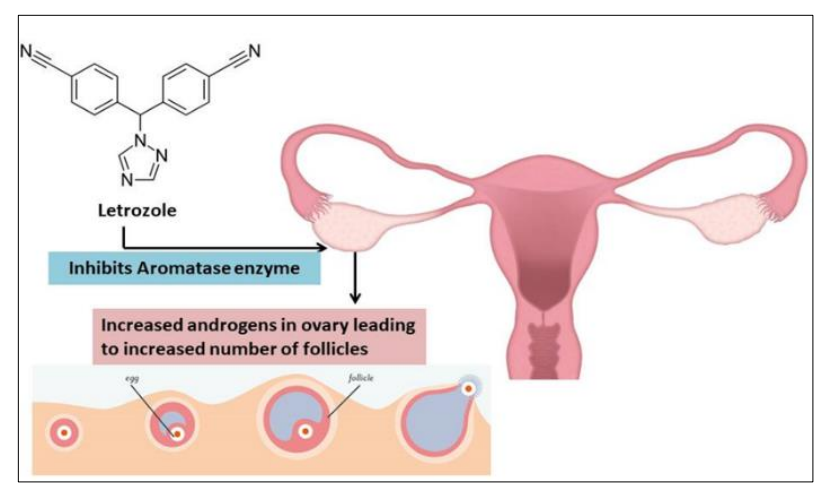

Figure 3: Peripheral mechanism of action (at level of cervix and endometrium). ${ }^{22}$

The favorable clinical implications of Letrozole are mentioned in Table 2.

\section{DISCUSSION}

\section{Efficacy of Letrozole in overcoming infertility in various population}

\section{a. In patients with PCOS (Table 3)}

Wang L et al studied 160 patients with PCOS and randomized them to receive $50 \mathrm{mg}$ /day Clomiphene citrate and $2.5 \mathrm{mg} /$ day Letrozole for ovulation induction. The endometrial thickness with Letrozole was found to be $10.8 \mathrm{~mm}$ in comparison to $7.8 \mathrm{~mm}$ with Clomiphene citrate. Due to improved endometrial thickness, pregnancy rates were also found to be higher with Letrozole i.e. $22.5 \%$ as compared to $10 \%$ with Clomiphene citrate as shown in Figure $4 .^{25}$

The efficacy of Letrozole versus Clomiphene citrate for infertility treatment in patients with anovulatory infertility caused by PCOS was evaluated in 200 patients. The biochemical pregnancy rate in Letrozole was found to be $35.5 \%$ along with higher live birth rate i.e. $28 \%$. With Clomiphene citrate, the biochemical pregnancy was found to be $28.8 \%$ with live birth rate $18 \%$ as shown in Figure $5 .{ }^{26}$ Chakravorty et al randomized 127 patients of infertility with PCOS receiving either $(2.5-5 \mathrm{mg})$ of Letrozole daily or 50-100 mg of Clomiphene citrate daily for 5 days starting on day 3 of menses. Ovulation in $37.87 \%$ in Letrozole group was observed as compared to $19.67 \%$ in Clomiphene citrate group. Endometrial thickness was found to be $9.82 \mathrm{~mm}$ in Letrozole group and $8.13 \mathrm{~mm}$ in Clomiphene citrate group. ${ }^{27}$ As shown in Figure 5, Legro et al studied 750 women with PCOS by randomizing them to receive Letrozole or Clomiphene citrate. In comparison to Clomiphene citrate, the ovulation rate was found to be higher in Letrozole group i.e. $61.7 \%$ as compared to $48.3 \%$ with Letrozole. 
Letrozole was also associated with higher live-birth ie. $27.5 \%$ as compared to $19.1 \%$ with Clomiphene citrate. ${ }^{28}$ As shown in Figure 4, Roy et al randomized 204 patients with PCOS to receive 2.5-5 mg of Letrozole and 50-100 $\mathrm{mg}$ of Clomiphene citrate. The pregnancy rate with Letrozole was significantly higher i.e. $43.8 \%$ as compared to $26.4 \%$ with Clomiphene citrate. ${ }^{29}$

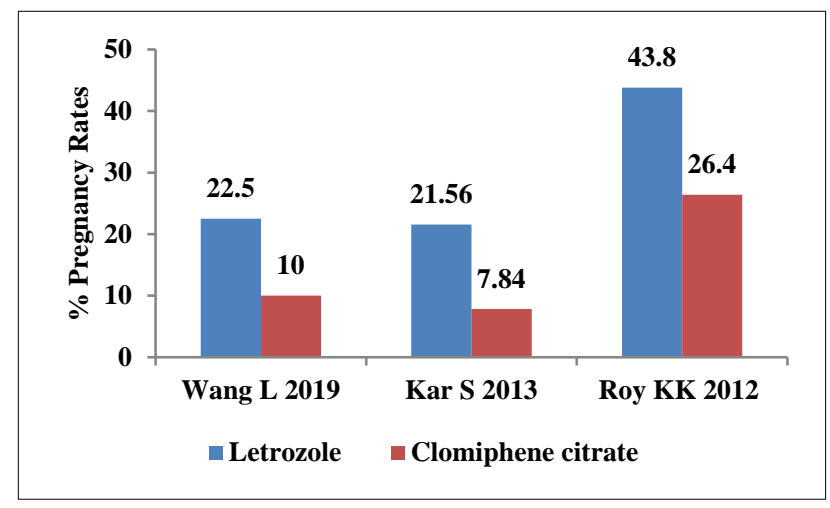

Figure 4: Pregnancy rates $(\%)$ comparing Letrozole and Clomiphene citrate in patients with PCOS. ${ }^{23,25,29}$

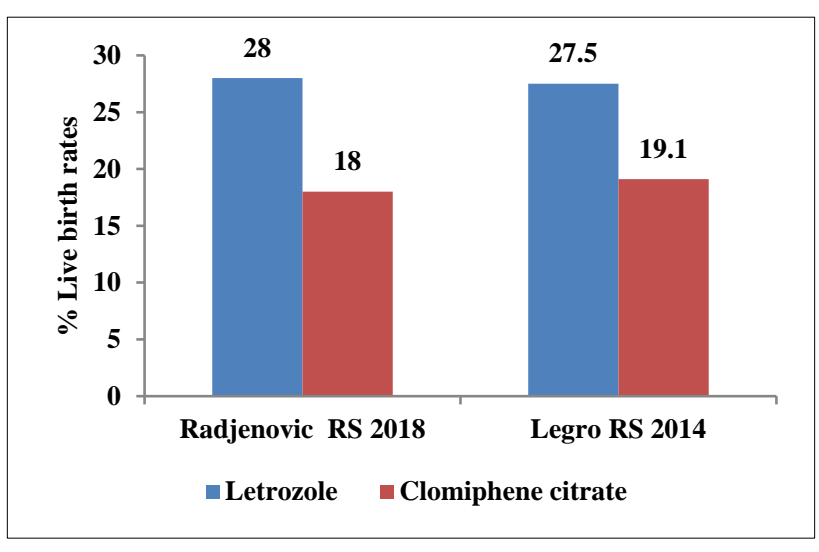

Figure 5: Live birth rate (\%) comparing Letrozole and Clomiphene citrate in patients with PCOS. ${ }^{26,28}$

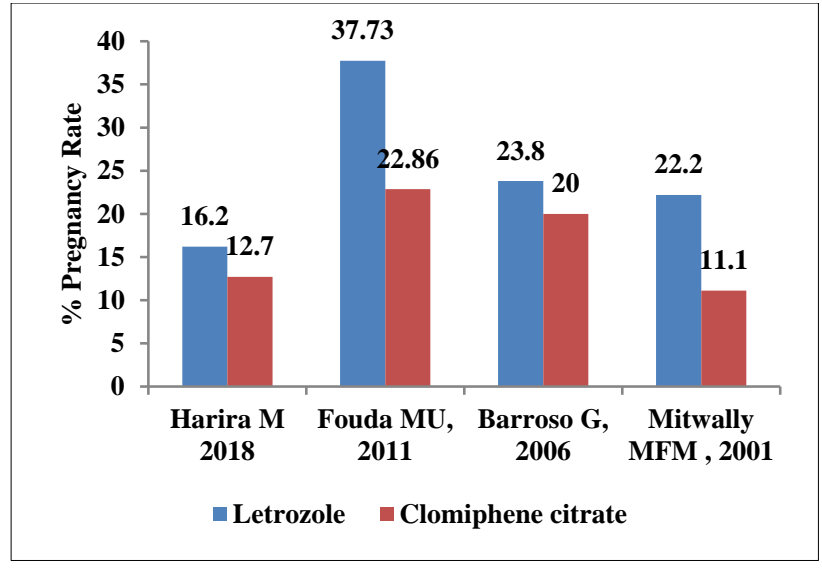

Figure 6: Pregnancy rate (\%) comparing Letrozole and Clomiphene citrate. ${ }^{30-33}$

b. In patients with unexplained infertility (Table 4)

Harira randomized 172 women with unexplained infertility with improper endometrial response to Clomiphene citrate were randomized to receive $100 \mathrm{mg}$ Clomiphene citrate and $4 \mathrm{mg}$ Estradiol Valerate on the $8^{\text {th }}$ day of menstruation until $14^{\text {th }}$ day and $5 \mathrm{mg}$ Letrozole from day 3 to 7 of menstruation. The endometrial thickness in Letrozole group was significantly higher i.e. $9.2 \mathrm{~mm}$ as compared to Clomiphene citrate i.e. $8.28 \mathrm{~mm}$. The pregnancy rate was similar in Letrozole and Clomiphene citrate group i.e. $16.2 \%$ versus $12.7 \%$ respectively as shown in Figure $6 .^{30}$ Fouda et al randomized 214 patients with unexplained infertility were treated by either Letrozole $2.5 \mathrm{mg} /$ day from cycle day 1 to 9 (extended protocol) or Clomiphene citrate 100 $\mathrm{mg}$ /day from cycle day 3 to 7 . Endometrial thickness in extended protocol of Letrozole was significantly greater i.e. $9.10 \mathrm{~mm}$ as compared to Clomiphene citrate i.e. 8.18 $\mathrm{mm}$. The cumulative pregnancy rate in Letrozole was observed to be $37.73 \%$ as compared to $22.86 \%$ in Clomiphene citrate group as shown in Figure $6 .{ }^{31} 32$

Table 3: Summary of Letrozole trials in PCOS patients.

\begin{tabular}{|c|c|c|c|}
\hline Author & Patient/condition & Treatment & Outcome \\
\hline Wang $\mathrm{L}^{25}$ & $\begin{array}{l}160 \text { patients with } \\
\text { PCOS }\end{array}$ & $\begin{array}{l}\text { Letrozole } 2.5 \mathrm{mg} / \text { day (for } 1 \text { cycle) } \\
\text { versus } \\
\text { Clomiphene citrate } 50 \mathrm{mg} / \text { day (for } 1 \text { cycle) }\end{array}$ & $\begin{array}{l}\text { Ongoing pregnancy rate }(\%) \\
\text { Letrozole: } 22.5 \% \\
\text { Clomiphene citrate: } 10 \% \\
\text { Endometrial thickness }(\mathbf{m m}) \\
\text { Letrozole: } 10.8 \mathrm{~mm} \\
\text { Clomiphene citrate: } 7.8 \mathrm{~mm}\end{array}$ \\
\hline $\begin{array}{l}\text { Radjenovic } \\
\mathrm{RS}^{26}\end{array}$ & $\begin{array}{l}200 \text { infertile } \\
\text { women with } \\
\text { PCOS }\end{array}$ & $\begin{array}{l}\text { Letrozole } 5 \mathrm{mg} / \text { day (for } 1 \text { cycle) } \\
\text { versus } \\
\text { Clomiphene citrate } 100 \mathrm{mg} / \text { day (for } 1 \text { cycle) }\end{array}$ & $\begin{array}{l}\text { Live birth rate }(\%) \\
\text { Letrozole: } 28 \\
\text { Clomiphene citrate: } 18\end{array}$ \\
\hline $\begin{array}{l}\text { Chakravorty } \\
\mathrm{R}^{27}\end{array}$ & $\begin{array}{l}127 \text { infertile } \\
\text { women having } \\
\text { anovulation due } \\
\text { to PCOS }\end{array}$ & $\begin{array}{l}\text { Letrozole } 2.5 \mathrm{mg} / \text { day (for } 1 \text { cycle) and } 5 \mathrm{mg} \\
\text { (for } 2^{\text {nd }} \text { cycle) } \\
\text { versus } \\
\text { Clomiphene citrate } 50 \mathrm{mg} / \text { day (for } 1^{\text {st }} \text { cycle) }\end{array}$ & $\begin{array}{l}\text { Endometrial thickness }(\mathbf{m m}) \\
\text { Letrozole: } 9.82 \mathrm{~mm} \\
\text { Clomiphene citrate: } 8.13 \mathrm{~mm} \\
\text { Ovulation }(\%)\end{array}$ \\
\hline
\end{tabular}




\begin{tabular}{|c|c|c|c|}
\hline Author & Patient/condition & Treatment & Outcome \\
\hline & & and $100 \mathrm{mg}$ (for $2^{\text {nd }}$ cycle) & $\begin{array}{l}\text { Letrozole: } 37.87 \\
\text { Clomiphene citrate: } 19.67\end{array}$ \\
\hline Legro $\mathrm{RS}^{28}$ & $\begin{array}{l}750 \text { infertile } \\
\text { women with } \\
\text { PCOS }\end{array}$ & $\begin{array}{l}\text { Letrozole } 2.5 \mathrm{mg} \text { daily (for upto five } \\
\text { menstrual cycles.) }\end{array}$ & $\begin{array}{l}\text { Ovulation rate }(\%) \\
\text { Letrozole: } 61.7 \\
\text { Clomiphene citrate: } 48.3 \\
\text { Live births }(\%) \\
\text { Letrozole: } 27.5 \\
\text { Clomiphene citrate: } 19.1\end{array}$ \\
\hline Roy $\mathrm{KK}^{29}$ & $\begin{array}{l}204 \text { patients of } \\
\text { anovulatory } \\
\text { PCOS. }\end{array}$ & $\begin{array}{l}\text { Letrozole: } 2.5 \mathrm{mg} / \text { day (for } 1 \text { cycle) } \\
\text { versus } \\
\text { Clomiphene citrate: } 50 \mathrm{mg} / \text { day (for } 1 \text { cycle) }\end{array}$ & $\begin{array}{l}\text { Endometrial thickness (mm) } \\
\text { Letrozole: } 9.1 \\
\text { Clomiphene citrate: } 6.3 \\
\text { Pregnancy Rates }(\%) \\
\text { Letrozole: } 43.8 \\
\text { Clomiphene citrate: } 26.4\end{array}$ \\
\hline
\end{tabular}

Table 4: Summary of Letrozole trials in patients with unexplained infertility.

\begin{tabular}{|c|c|c|c|}
\hline Author & Patient/condition & Treatment & Outcome \\
\hline Harira $\mathbf{M}^{30}$ & $\begin{array}{l}172 \text { patients with } \\
\text { unexplained } \\
\text { infertility for one } \\
\text { to three years }\end{array}$ & $\begin{array}{l}\text { Letrozole } 5 \mathrm{mg} \text { daily from cycle day } 3 \text { to day } \\
7 . \\
\text { versus } \\
\text { Clomiphene citrate } 100 \mathrm{mg} \text { and Estradiol } 4 \\
\mathrm{mg}\end{array}$ & $\begin{array}{l}\text { Endometrial thickness }(\mathbf{m m}) \\
\text { Letrozole: } 9.2 \\
\text { Clomiphene citrate: } 8.28 \\
\text { Pregnancy rate }(\%): \\
\text { Letrozole } 16.2 \\
\text { Clomiphene citrate: } 12.7\end{array}$ \\
\hline Fouda $\mathrm{MU}^{31}$ & $\begin{array}{l}214 \text { patients with } \\
\text { unexplained } \\
\text { infertility }\end{array}$ & $\begin{array}{l}\text { Letrozole: } 2.5 \mathrm{mg} / \text { day for } 10 \text { days (from day } \\
1 \text { to day } 9 \text { ) } \\
\text { versus } \\
\text { Clomiphene citrate: } 100 \mathrm{mg} \text { / day (for } 1 \\
\text { cycle) }\end{array}$ & $\begin{array}{l}\text { Endometrial thickness }(\mathbf{m m}) \\
\text { Letrozole: } 9.10 \\
\text { Clomiphene citrate: } 8.18 \\
\text { Cumulative pregnancy rate }(\%) \\
\text { Letrozole: } 37.73 \\
\text { Clomiphene citrate: } 22.86\end{array}$ \\
\hline Barroso $\mathrm{G}^{32}$ & $\begin{array}{l}41 \text { patients with } \\
\text { unexplained } \\
\text { infertility }\end{array}$ & $\begin{array}{l}\text { Letrozole: } 2.5 \mathrm{mg} / \mathrm{d} \text { for } 5 \text { days (for } 1 \text { cycle) } \\
\text { versus } \\
\text { Clomiphene citrate: } 100 \mathrm{mg} / \mathrm{d} \text { (for } 1 \text { cycle) }\end{array}$ & $\begin{array}{l}\text { Endometrial thickness }(\mathbf{m m}) \\
\text { Letrozole: } 9.5 \\
\text { Clomiphene citrate: } 7.3 \\
\text { Clinical pregnancy rate }(\%) \\
\text { Letrozole: } 23.8 \\
\text { Clomiphene citrate: } 20\end{array}$ \\
\hline $\begin{array}{l}\text { Mitwally } \\
\text { MFM }^{33}\end{array}$ & $\begin{array}{l}110 \text { women with } \\
\text { unexplained } \\
\text { infertility }\end{array}$ & $\begin{array}{l}\text { Letrozole }(2.5 \mathrm{mg} / \text { day from day } 3 \text { to day } 7)+ \\
\text { FSH } 50 \pm 150 \mathrm{IU} / \text { day } \\
\text { versus } \\
\text { Clomiphene citrate } 100 \mathrm{mg} \text { from day } 5 \text { to } \\
\text { day } 9 \text { of the } \\
\text { menstrual cycle }+ \text { FSH injection } 50 \pm 150 \\
\text { IU/day }\end{array}$ & $\begin{array}{l}\text { Total FSH dose/cycle }(\mathbf{I U}) \\
\text { Letrozole + FSH: } 465 \\
\text { Clomiphene Citrate + FSH: } \\
619 \\
\text { Clinical pregnancy rate }(\%) \\
\text { Letrozole: } 22.2 \\
\text { Clomiphene citrate: } 11.1\end{array}$ \\
\hline
\end{tabular}

Table 5: Summary of Letrozole trials in patients with Clomiphene resistance.

\begin{tabular}{|c|c|c|c|}
\hline Author & Patient/condition & Treatment & Outcome \\
\hline Ibrahim $\mathrm{MH}^{34}$ & $\begin{array}{l}80 \text { women with Clomiphene } \\
\text { citrate-resistant PCOS }\end{array}$ & $\begin{array}{l}\text { Letrozole } 2.5 \mathrm{mg} / \mathrm{day} \\
\text { (for up to six cycles.) } \\
\text { versus } \\
\text { Laparoscopic drilling } \\
\text { (LOD) }\end{array}$ & $\begin{array}{l}\text { Ovulation rate }(\%) \\
\text { Letrozole: } 70 \\
\text { LOD: } 57.5 \\
\text { Pregnancy rate }(\%) \\
\text { Letrozole: } 35 \\
\text { LOD: } 27.5\end{array}$ \\
\hline Nabih EL-Gharib 35 & $\begin{array}{l}60 \text { infertile women with } \\
\text { Clomiphene resistant PCOS }\end{array}$ & $\begin{array}{l}\text { Letrozole } 2.5 \\
\text { mg/day (for } 5 \text { days) } \\
\text { versus } \\
\text { Tamoxifen } 20 \mathrm{mg} / \text { day } \\
\text { (for } 5 \text { days) }\end{array}$ & $\begin{array}{l}\text { Endometrial thickness (mm) } \\
\text { Letrozole: } 10.2 \\
\text { Tamoxifen: } 9.1 \\
\text { Ovulation (\%) } \\
\text { Letrozole: } 23.33\end{array}$ \\
\hline
\end{tabular}




\begin{tabular}{|c|c|c|c|}
\hline Author & Patient/condition & Treatment & Outcome \\
\hline & & & Tamoxifen: 8.89 \\
\hline Rahmani $\mathrm{E}^{36}$ & $\begin{array}{l}44 \text { clomiphene-resistant } \\
\text { infertile patients }\end{array}$ & $\begin{array}{l}\text { Letrozole given in } \\
\text { incremental dose of } 2.5 \\
\mathrm{mg} \text { (first cycle), } 5 \mathrm{mg} \\
\text { (second cycle), and } 7.5 \\
\text { mg (third cycle) }\end{array}$ & $\begin{array}{l}\text { Ovulation rate }(\%) \\
\text { Letrozole: } 44.24 \\
\text { Pregnancy rate }(\%) \\
\text { Letrozole: } 23.89\end{array}$ \\
\hline Elnashar $\mathrm{A}^{37}$ & $\begin{array}{l}44 \text { infertile women with } \\
\text { Clomiphene citrate resistance }\end{array}$ & $\begin{array}{l}\text { Letrozole: } 2.5 \mathrm{mg} \text { (for } \\
1 \text { cycle) }\end{array}$ & $\begin{array}{l}\text { Ovulation rate }(\%) \\
\text { Letrozole: } 54.6 \\
\text { Pregnancy rate }(\%) \\
\text { Letrozole: } 25\end{array}$ \\
\hline
\end{tabular}

Barroso $\mathrm{G}$ et al randomized 41 patients with unexplained infertility undergoing intrauterine insemination (IUI) therapy to receive either Letrozole or Clomiphene citrate along with rFSH. Endometrial thickness observed in Letrozole group was $9.5 \mathrm{~mm}$ as compared $7.3 \mathrm{~mm}$ with Clomiphene citrate. The clinical pregnancy rate was in Letrozole group was non-significant to Clomiphene citrate i.e. 23.8\% versus $20 \%$ as shown in Figure 6.

c. In patients with Clomiphene resistance (Table 5)

Ibrahim $\mathrm{MH}$ et al studied 80 women with CC-resistant PCOS who were randomly allocated to undergo laparoscopic ovarian drilling (LOD) or receive $2.5 \mathrm{mg}$ letrozole from days 3 to 7 of menses for up to six cycles. A higher ovulation rate was found in Letrozole group i.e. $70 \%$ as compared to patients who underwent LOD i.e. $57.5 \%$ as shown in Figure 7. Pregnancy rate in Letrozole group was $35 \%$ as compared to in LOD group which was found to be $27.5 \% .{ }^{34}$ Gharib NE et al studied 60 infertile women with PCOS and Clomiphene citrate resistance who were randomized to receive $2.5 \mathrm{mg}$ /day of Letrozole or $20 \mathrm{mg} /$ day of Tamoxifen daily for 5 days from day 5 of menses. The endometrial thickness and ovulation rate was found to be higher in Letrozole i.e.10.2 $\mathrm{mm}$ and $23.33 \%$ respectively as compared to $9.1 \mathrm{~mm}$ and $8.89 \%$ in Clomiphene citrate group as shown in Figure $7 .^{35}$ Rahmani E et al observed 44 clomiphene-resistant infertile patients who were randomized to receive $2.5 \mathrm{mg}$, $5 \mathrm{mg}$, and $7.5 \mathrm{mg}$ of Letrozole. The ovulation and pregnancy rate were found to be $44.24 \%$ and $23.89 \%$ respectively. ${ }^{36}$ Elnashar A et al studied 44 infertile women with Clomiphene citrate resistance who received Letrozole $2.5 \mathrm{mg} /$ day for 5 days. The ovulation rate and pregnancy rate was found to be $54.6 \%$ and $25 \%$ respectively. ${ }^{37}$

\section{Letrozole - the road ahead}

a. Potential role in endometriosis associated infertility

Endometriosis-associated infertility represents a therapeutic dilemma because of ovulatory dysfunction related to altered folliculogenesis as well as impaired steroidogenesis of granulosa cells, impaired fertilization, low quality embryos, defective implantation, sperm phagocytosis, embryo - toxic environment and pelvic adhesions in advanced stages. ${ }^{38}$ Standard medical treatments aim either at inducing hypoestrogenism or at antagonizing estrogen action since estrogen is released aberrantly in endometriosis. Estrogen is a potent stimulator of cyclooxygenase 2 (COX-2) in uterine endothelial cells which in turn forms prostaglandin E2 from arachidonic acid which leads to painful stimuli in patients with endometriosis. ${ }^{39}$

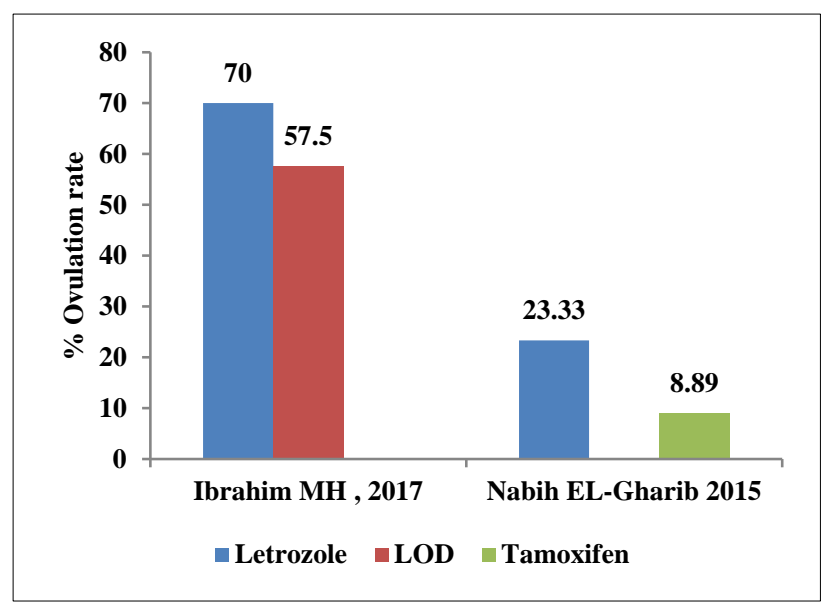

Figure 7: Comparative ovulation rate $(\%) .^{34,35}$

The molecular basis for the use of aromatase inhibitors is that they suppress estrogen production in peripheral tissues to decrease circulating estrogen levels considerably thereby reducing further proliferation of endometriotic lesions and painful stimuli. Letrozole has a significant reduction in total body estrogen (97-99\%) and hence shown high efficacy in symptomatic management of endometriosis. ${ }^{40}$ Mitra et al studied the effects of Letrozole and Leuprolide, a GnRH agonist in women from 18-45 years of age with symptomatic (pain) endometriosis. The results showed that mean decrease of visual analogue score (VAS) before and after 3 months of treatment with Letrozole was highly significant and comparable to Leuprolide. However, it was observed that the safety profile of Letrozole was better as compared to Leuprolide. $^{41}$ 


\section{b. Potential role in male infertility}

Firty percent of infertility cases is attributed to multiple causes including abnormalities in sperm parameters like sperm concentration, count, motility, vitality and morphology. ${ }^{42}$ In Males, aromatase is present in testis (particularly in Leydig and Sertoli cells), liver and brain.

This enzyme is responsible for the conversion of testosterone to estradiol and androstenedione to estrone. Aromatase inhibitors have found its role in increasing endogenous testosterone production by inhibiting the conversion of testosterone to estradiol and androstenedione to estrone leading to an increase in spermatogenesis. $^{43}$

\section{Letrozole - addressing key issues}

A significant proportion of success rate in inducing ovulation and achieving pregnancy in women with anovulatory infertility i.e. PCOS and unexplained infertility has been achieved with Letrozole which is one of the third-generation aromatase inhibitors (AIs). The major standout point for Letrozole is its lack of antiestrogenic effects due to its shorter half-life thereby preserving the feedback mechanism of hypothalamicpituitary-ovarian axis. This ensures monofollicular growth leading to singleton pregnancies thereby avoiding the co-morbidities associated with multiple pregnancies. Letrozole used in higher doses can enhance the follicular growth without detrimental effects on the endometrium thereby allowing more and more patients to retain on oral therapy without shifting to expensive gonadotropin therapy or in vitro-fertilization.

The clinical evidences wherein Letrozole has been used as first line therapy for ovulation induction is ever increasing making Letrozole an important tool in the infertility treatment armamentarium.

Funding: No funding sources Conflict of interest: None declared

Ethical approval: Not required

\section{REFERENCES}

1. Norwitz E, Schust DJ, Fisher SJ. Implantation and the survival of early pregnancy. $\mathrm{N}$ Engl $\mathrm{J}$ Med. 2001;345:1400-8.

2. Gurunath S, Pandian Z, Anderson RA, Bhattacharya S. Defining infertility-a systematic review of prevalence studies. Human Repro Update. 2011;17(5):575-88.

3. Practice Committee of American Society for Reproductive Medicine. Diagnostic evaluation of the infertile female: a committee opinion. Fertil Steril. 2012;98(2):302-7.

4. Singh K, Kumari R, Ranjan R, Bharti G. Analysis of causes and clinical pattern of infertility in couples coming to a tertiary care centre in Bihar, India. Int $\mathrm{J}$
Reprod Contracept Obstet Gynecol. 2017;6(6):227983.

5. Mittal S. Investigating infertility. In: Gutgutia R Infertility management series. $1^{\text {st }}$ edition. Jaypee Brothers Med Publishers (P) Ltd; 2018:356-357.

6. Mascarenhas MN, Cheung H, Mathers CD, Stevens GA. Measuring infertility in populations: constructing a standard definition for use with demographic and reproductive health surveys. Population Health Metrics. 2012;10:17.

7. Gokler ME, Unsal A, Arslantas D. The prevalence of infertility and loneliness among women aged 18-49 years who are living in semi-rural areas in Western Turkey. Int J Fertil Steril. 2014;155-162.

8. Sharma KS, Biedenharn KR, Fedor J, Agarwal A. Lifestyle factors and reproductive health: Taking control of your fertility. Repro Biol Endocrinol. 2013;11(1):66.

9. Bhattacharya S, Johnson N, Tijani HA, Hart R, Pandey S, Gibreel AF. Female infertility. BMJ Clin Evid. 2010;2010:0819.

10. Lin PC, Bhatnagar KP, Stephen N, Nakajima TN. Female genital anomalies affecting reproduction. Fertil Steril. 2002;78:899-915.

11. Katsikis I, Kita M, Karkanaki A, Prapas N, Panidis D. Anovulation and ovulation induction. Hippokratia. 2006;10(3):120-7.

12. Homburg R. Clomiphene citrate-end of an era? a mini-review. Human Repro. 2005;20(8):2043-51.

13. Snegovskikh VV. Clomiphene citrate (CC) administration changes cervical mucus permeability in patients undergoing fertility treatments. Fert Steril. 2014;102(3):e306

14. Wada M, Kasai T, Nagai S, Fujie M, Miyake M, Suzuk K, et al. Effect of repeated administration of clomiphene citrate at two different times on the endometrium in patients undergoing intrauterine insemination. Repro Med Biol. 2004;3:153-7.

15. Omran E, Sharkawy ME, Mazny AE, Hammam M, Ramadan W, Latif D, et al. Effect of clomiphene citrate on uterine hemodynamics in women with unexplained infertility. Int $\mathrm{J}$ Womens Health. 2018;10:147-52.

16. Ergur AR, Yergok YZ, Ertekin A, Kuçuk T, Mungen E, Tutuncu L. Clomiphene citrate-resistant polycystic ovary syndrome. Preventing multifollicular development. J Reprod Med. 1998;43(3):185-90.

17. Saha L, Kaur S, Saha PK. N-acetyl cysteine in clomiphene citrate resistant polycystic ovary syndrome: a review of reported outcomes. J Pharmacol Pharmacother. 2013;4(3):187-91.

18. Kamath MS, George K. Letrozole or clomiphene citrate as first line for anovulatory infertility: a debate. Repro Biol Endocrinol. 2011;9:86.

19. Karaer O, Oruc S, Koyuncu FM. Aromatase inhibitors: possible future applications. Acta Obstet Gynecol Scand. 2004;83:699-706. 
20. Casper RF, Mitwally MF. A historical perspective of aromatase inhibitors for ovulation induction. Fertil Steril. 2012;98(6):1352-5.

21. Takasaki A, Tamura H, Taketani T, Shimamura K, Morioka H, Sugino N. A pilot study to prevent a thin endometrium in patients undergoing clomiphene citrate treatment. J Ovarian Res. 2013;6(1):94.

22. Mitwally MFM, Casper RF. Aromatase Inhibitors in Ovulation Induction. Semin Reprod Med. 2004;22(1):61-78.

23. Kar S. Current evidence supporting "letrozole" for ovulation induction. J Hum Reprod Sci. 2013;6(2):93-8.

24. Pritts EA, Yuen AK, Sharma S, Genisot R, Olive DL. The use of high dose letrozole in ovulation induction and controlled ovarian hyperstimulation. ISRN Obstet Gynecol. 2011;2011:242864.

25. Wang L, Wen X, Lv S, Zhao J, Yang T, Yang. Comparison of endometrial receptivity of clomiphene citrate versus letrozole in women with polycystic ovary syndrome: a randomized controlled study. Gynecol Endocrinol. 2019;12:1-4.

26. Radjenovic SS, Peulic LS, Gudovic A, Vidakovic S, Bila J. Letrozole versus clomiphene as the first-line treatment for anovulatory infertility in women with PCOS, 2018. Available at: https://isge2018.isgesociety.com/wp-

content/app/abs/pdf/abs7373.pdf. Accessed on $6^{\text {th }}$ June 2019.

27. Chakravorty R, Athwal A, Sur D, Saha R. A prospective, randomized trial comparing the effects of letrozole versus clomiphene citrate for induction of ovulation and pregnancy rate in women with polycystic ovary syndrome. Fertil Sci Res. 2016;3:93-7.

28. Legro RS, Brzyski RG, Diamond MP, Coutifaris C, Schlaff WD, Casson P, et al. Letrozole versus Clomiphene for Infertility in the Polycystic Ovary Syndrome. N Engl J Med. 2014;371:119-29.

29. Roy KK, Baruah J, Singla S, Sharma JB, Singh N, Jain SK, et al. A prospective randomized trial comparing the efficacy of Letrozole and Clomiphene citrate in induction of ovulation in polycystic ovarian syndrome. J Hum Reprod Sci. 2012;5(1):20-5.

30. Harira M. Use of Letrozole versus clomipheneestradiol for treating infertile women with unexplained infertility not responding well to clomiphene alone, comparative study. Middle East Fertility Society J. 2018;23(4):384-8.

31. Fouda UM, Sayed AM. Extended letrozole regimen versus clomiphene citrate for superovulation in patients with unexplained infertility undergoing intrauterine insemination: a randomized controlled trial. Reprod Biol Endocrinol. 2011;9:84.

32. Barroso G, Menocal G, Felix H, Rojas-Ruiz JC, Arslan M, Oehninger S. Comparison of the efficacy of the aromatase inhibitor letrozole and clomiphene citrate as adjuvants to recombinant folliclestimulating hormone in controlled ovarian hyperstimulation: a prospective, randomized, blinded clinical trial. Fertil Steril. 2006;86(5):1428-31.

33. Mitwally MF, Casper RF. Use of an aromatase inhibitor for induction of ovulation in patients with an inadequate response to clomiphene citrate. Fertil Steril. 2001;75:305-9.

34. Ibrahim MH, Tawfic M, Hassan MM, Sedky OH. Letrozole versus laparoscopic ovarian drilling in infertile women with PCOS resistant to clomiphene citrate. Middle East Fertil Soc J. 2017:1-4.

35. EL-Gharib MN, Mahfouz AE, Farahat MA. Comparison of Letrozole versus Tamoxifen effects in Clomiphen citrate resistant women with polycystic ovarian syndrome. J Reprod Infertil. 2015;16(1):305.

36. Rahmani E, Ahmadi S, Motamed N, Maneshi HO. Dosage optimization for Letrozole treatment in Clomiphene-resistant patients with polycystic ovary syndrome: a prospective interventional study. Obstet Gynecol Int. 2012;2012:758508.

37. Elnashar A, Fouad H, Eldosoky M, Saeid N. Letrozole induction of ovulation in women with clomiphene citrate-resistant polycystic ovary syndrome may not depend on the period of infertility, the body mass index, or the luteinizing hormone/follicle-stimulating hormone ratio. Fertil Steril. 2006;85(2):511-3.

38. Hashim HA. Aromatase inhibitors for endometriosisassociated infertility; do we have sufficient evidence? Int J Fertil Steril. 2016;10(3):270-7.

39. Sacco K, Portelli M, Pollacco J, Wismayer SP, Agius JC. The role of prostaglandin E2 in endometriosis. Gynecol Endocrinol. 2012;28(2):134-8.

40. Pavone ME, Bulun SE. Aromatase inhibitors for the treatment of endometriosis. Fertil Steril. 2012;98(6):1370-9.

41. Mitra PS, Sirazee HH, Latha B.V, Dasgupta M, Adhikari S. A prospective randomized comparative study of Letrozole versus Leuprolide acetate in symptomatic relief of endometriosis. Int $\mathbf{J}$ Pharma Sci Invent. 2013;2(6):32-8.

42. Kumar N, Singh AK. Trends of male factor infertility, an important cause of infertility: a review of literature. J Hum Reprod Sci. 2015;8(4):191-6.

43. de Ronde W, de Jong FH. Aromatase inhibitors in men: effects and therapeutic options. Reprod Biol Endocrinol. 2011;9:93.

Cite this article as: Maladkar M, Tekchandani C, Karchodi A. Letrozole: an emerging array of hope for infertile women. Int J Reprod Contracept Obstet Gynecol 2020;9:891-9. 